\title{
Practical Nous as the Aim of Legal Education?
}

\section{Graham Ferris* \\ Nick Johnson**}

There has been an implicit assumption that legal education should be about exposition and evaluation, and should reward facility in exposition and theoretical awareness. This theoretically based assumption generates a theory-induced blindness. Specifically, it obscures the dynamic relationship between law and legal practice, despite it being a familiar aspect of the world. The lawyer as rule entrepreneur is lost sight of. One alternative assumption about legal education would be that law is a game like activity; and legal education should be directed towards promoting those qualities that would enhance performance in this game. In this approach to legal education it would be practical nous that would be sought and rewarded, and such qualities as facility in exposition and theoretical awareness would receive recognition merely as qualities that can be ancillary to and elements of practical nous. Doctrinal legal education naturally pulls towards the first theory, and clinical legal education naturally pulls towards the second. We argue for a clearer awareness of the role of rule entrepreneurship in clinical programmes and in legal education generally.

\section{Theories: how they illuminate and how they obscure}

Daniel Kahneman, in his popular summary of his work in behavioural psychology, refers to "theory-induced blindness": an idea he calls upon to explain why even quite obvious (in retrospect) errors in science may have significant longevity. ${ }^{1}$ All models of the world are simplifications, ignoring some features of the world in order to focus attention upon other features common across different specific activities. ${ }^{2}$ This focus enables analysts to penetrate surface difference and understand at a common or deeper level, it enables us to learn from the experience of others and from the past: to see how Tulip mania demonstrated many of the same features as the market in sub-prime mortgage derivatives. ${ }^{3}$ Many successful scientific theories have what Ian Glynn refers to as "elegance" a quality that combines parsimony with a feeling of axiomatic certitude:

* Graham Ferris, Reader, College of Business,Law and Social Sciences, Nottingham Law School, Nottingham Trent University.

** Nicholas Johnson, Principal Lecturer, College of Business Law and Social Sciences, Nottingham Law School, Nottingham Trent University.

1 Daniel Kahneman, Thinking, Fast and Slow (2011) Allen Lane: London at 277.

2 Thomas Schelling, Micromotives and Macrobehaviour (2006) Norton: New York, NY at 83-133.

3 Charles Kindleburger and Robert Aliber, Manias, Panics and Crashes (2005) Palgrave Macmillan: Houndmills 
both uncluttered and convincing. ${ }^{4}$ An elegant theoretical model that can be usefully deployed is a powerful and attractive educational tool but is one that can induce a blindness that seriously distorts educational programmes. We feel contemporary doctrinal legal education suffers from such distortion, specifically that it is blind to the role of lawyers in practice in changing rules.

This article attempts to articulate an approach to law and legal education that is centred not in exposition, which rewards generality and logical consistency, but in practice, that rewards alertness to potential distinctions and goal directed efficacy. We use the old term of Greek thought "nous" to try and put this approach into a historical and theoretical context. The problem of reason in practice was explored by Aristotle, and for him nous was an essential part of his approach to "phronesis" or practical wisdom - how to act well and rationally, rather than how to reason well and rationally. ${ }^{5}$ We felt "nous" both connected to the Aristotelian tradition and maintained some contemporary resonance, "nous" is used in modern English to mean (according to the New Shorter Oxford English Dictionary): “common sense, practical intelligence, gumption”. We want to move the inculcation of nous, and support of the potential to develop nous, into the centre of legal education. ${ }^{6}$ At present we feel legal education is too focused upon the "know that" or exposition of law, and too little concerned with practical nous or creative use of the law. ${ }^{7}$ Nous is concerned with how one achieves one's purposes using the resources that are available; as such it is concerned with purposes and effectiveness in action.

Once the importance and independence of nous as an educational end is realised the role of clinical legal education is cast in a new light. The development of skills, basic and advanced, can no longer be seen as the purpose of experiential learning. This aspect becomes a means towards a more ambitious end. Facilitating the establishment of nous in the student, and preparation for a lifelong

4 Ian Glynn, Elegance in Science (2010) Oxford University Press: Oxford.

5 Aristotle, The Nicomachean Ethics (London: Penguin Books, 2004) tr. J.A.K. Thomson. Rosalind Hursthouse, Practical Wisdom: A Mundane Account (2006) 106 Proceedings of the Aristotelian Society 285-309. Hursthouse's is an illuminating commentary: "... Aristotle says about practical nous in Book VI, and, in stressing the point that practical nous is akin to perceptual capacity rather than the knowledge that some general principles hold ..." at 287 ; and "... this entirely mundane, non-moral sort of 'technical' expertise is essential to practical wisdom." at 305 .

6 Of all qualities nous must be one that is a lifelong learning project, as was recognised by Aristotle. Peter Jarvis, Learning to be an expert: competence development and expertise, in Teaching, Learning and Education in Late Modernity (2012) Routledge: Abingdon at p. 91 refers to: "the old debates about knowledge and skill" and calls for a focus upon "what it really means for whole people to learn" in relation to vocational education, and he goes on to cite J. Delors Learning: The treasure within (1996) UNESCO: Paris "in which there are four pillars of learning - to be, to do, to know and to live together". Nous is concerned with all four pillars, with "to do" being centre stage.

7 In 1930 Karl Llewellyn, The Bramble Bush (1996) Oceana Publications, Inc.: New York, NY at p. 116: "The hardest job of the first year is to lop off your common sense, knock your ethics into temporary anesthesia." There is reason to think such an approach persists into modern practice: "We certainly discovered that the same process is very much at work in today's law schools. Faculty, like students, vary considerably as to how worrisome they find this 'lopping' and 'knocking,' this temporary moral lobotomy. However, virtually everyone with whom we spoke was aware that this process was a major facet of the case-dialogue pedagogy of the first year." William M, Sullivan, Anne Colby, Judith Welch Wegner, Lloyd Bond, Lee S. Shulman Educating Lawyers: Preparation for the Profession of Law (2007) Jossey-Bass: San Francisco, CA at loc. 1116. Common sense combined with ethical awareness, comes close to being a useable if partial definition of nous. Of course Llewellyn was not under the illusion that the educational aim of inculcating "thinking like a lawyer" in the first year sufficed for a complete, or even an acceptable legal education: "For a mere legal machine is a social danger. Indeed, a mere legal machine is not even a good lawyer. It lacks insight and judgment, It lacks the power to draw into hunching that body of intangibles that lie in social experience." Despite these misgivings he felt the process a necessary one after which: "we shall then duly endeavour to develop will, we hope, regain the homo." Ibid. at 116-117. 
cultivation of nous in practice (whether that practice be legal or not, as nous is useful in any life), become ultimate purposes that should inform clinical legal education.

\section{Legal Education: modernity and the rejection of Aristotle}

When one realises the deep links between nous and legal practice then at first blush it is hard to understand why legal education should have neglected practical nous and embraced theoretical elaboration. ${ }^{8}$ However it is not only legal education that has shown this prejudice against practical wisdom: ${ }^{9}$

"The idea that all the practical arts owe a debt to the skills Aristotle calls phronesis was not especially welcome to rational-minded thinkers in the modern period. Although, in its Latinized form prudence, this term keeps a place in words like jurisprudence, its broader implications are largely forgotten."

The problem was bound up with the self-image of modernity (c. 1600 to present) and the philosophical quest for certainty. The reputation of Aristotle's works on practical wisdom was contaminated by the rejection of his physics: ${ }^{10}$

"Both good and evil consequences resulted when philosophy turned its back on Aristotle ... Aristotle's physics was hopelessly erroneous, and had been shown to be so ... but for philosophy in the narrow sense ... there were losses as well as gains resulting from the abandonment of Aristotle."

The modern philosopher would find certainty by deduction from indubitable first principles, and no longer rely upon the authority of tradition. ${ }^{11}$ The Greek model was Euclid rather than Aristotle. At the birth of university legal education in the common law Blackstone had allowed a traditional and pious, if vague and unsystematic, natural law spirit to inform his Commentaries

8 Of course the neglect has not been total. We are not the first to sense incongruence between the claims of theory and the evidence of practice. Karl Llewellyn and E. Adamson Hoebel, The Cheyenne Way: conflict and case law in primitive jurisprudence (1941) University of Oklahoma: Norman, OK at p. 42: "When seen thus [i.e. when law is seen as working tools for the solution of problems that arise outside of law], each legal concept becomes a candle to illumine the working of society. It became a concept because some type of problem has recurred often enough, has required to be wrestled with often enough, to be not only felt but seen, as a type of problem. Every legal concept represents then in first instance an effort at diagnosis of a recurrent social trouble of some particular kind. ... Comparative study is to this extent a study in comparative diagnosis, if really similar problems have occurred in different cultures." Here the implication is clearly that practice generates law, that the solution of recurrent problems gives rise to the principles, and rules, and processes of law. Elsewhere Llewellyn described law as a craft activity, again to give emphasis to the practical nature of the subject. However, his attempt to describe and analyse the good and excellent, the ideal, became difficult to distinguish from mere subjective preference or taste. Despite his earnest attempts to demonstrate the grand style of judgment through examples the distinguishing features remained elusive, and no clear paradigm could be discerned, see: Karl Llewellyn, The Common Law Tradition: deciding appeals (1960) Little, Brown: Boston.

9 Steven Toulmin, Return to Reason (2003) Harvard University Press: Cambridge, Mass loc 1525-26

10 Anthony Kenny, The Rise of Modern Philosophy (2006) Clarendon Press: Oxford at xii-xiii.

11 Rene Descartes is "often considered the father of modern philosophy" Kenny, Ibid. at 33. 
on the Laws of England, ${ }^{12}$ but it was the irritated and contemptuous reaction to his confused reflections by Jeremy Bentham that would dominate the jurisprudence and educational practice of the nineteenth and twentieth centuries.

Legal education in the common law world is built upon an elegant and powerful model that reflects a distinction made over two centuries ago by Bentham between the expositor and the censor of law. " 13 "To the province of the Expositor it belongs to explain to us what, as he supposes, the law is: to that of the Censor, to observe to us what he thinks it ought to be." This basic distinction between the two roles, and the dependence of the second upon the first, has been defended and re-asserted expressly on many occasions. ${ }^{14}$ However, it is the relationships between the theoretical Expositor and the professional lawyer and legal education that concern us here.

Essentially, the expert knowledge and skills that underpin the claim of professional status are often equated with the role of the expositor. The lawyer does not claim any exclusive authority as censor of the law; such matters are in the realm of policy and politics. However, the lawyer does claim expertise in knowledge of what the law demands and how the legal system operates. The realm of exposition is the particular subject matter of legal studies, and as exposition is logically prior to the censoring of law, the sole remaining issue is how much policy, or politics, or ethics, or social science, or other sources of evaluative standards, should be included in legal education.

\section{Theory and Practice: "The question is," said Humpty Dumpty, "which is to be master - that's all."}

One effect of this theoretical approach to law is that is lends itself to an associated set of beliefs about the relationship between theory and practice. In short it seems obvious that theory, the principles and rules of legal doctrine, and the principles and systems of procedure, are the starting point. The practitioner will then derive more specific guidance by application of the general to the specific circumstances of the case or the client. Legal science mirrors the methodology of deduction of particulars from principles of modern philosophy. Doctrine is prior and governing; clinical action and education is subsequent and governed. Stephen Toulmin suggests a very different relationship between theory and practice: ${ }^{15}$

12 Available at: http://avalon.law.yale.edu/subject_menus/blackstone.asp last accessed 27 May 2013. Legal education in the common law had taken place in the Inns of Court for centuries, and university education in the civil (Roman) law had taken place in the Universities. However, common law education in the University made a stuttering start in the eighteenth century when Blackstone was appointed to the Vinerian Chair at Oxford in 1758. In "Of the Nature of Laws in General" Blackstone starts by confounding scientific laws with the laws governing people, then proceeds to confound the laws of God with Roman law and the common law: "CONSIDERING the creator only as a being of infinite power ... he is also a being of infinite wisdom, he has laid down only such laws as were founded in those relations of justice, that existed in the nature of things antecedent to any positive precept. These are the eternal, immutable laws of good and evil, to which the creator himself in all his dispensations conforms; and which he has enabled human reason to discover, so far as they are necessary for the conduct of human actions. Such among others are these principles: that we should live honestly, should hurt nobody, and should render to every one it's due; to which three general precepts Justinian has reduced the whole doctrine of law." The whole section is redolent of a rhetorical flourish rather than a serious attempt to analyse and reflect upon the connections between different contemporary usages of the word and concept "law". Bentham was not given to recognising the propriety of rhetorical flourishes.

13 Jeremy Bentham, A Fragment On Government, Preface (1998) Cambridge University Press: Cambridge at 7

14 H.L.A. Hart, Positivism and the Separation of Law and Morals (1958) 71 Harv. L. R. 593.

15 Steven Toulmin, Return to Reason (2003) Harvard University Press: Cambridge, Mass loc. 1762-63. 
"Theory (so to speak) is not a foundation on which we can safely construct Practice; rather, it is a way of bringing our external commitments into line with our experience as practitioners."

This is an aspect of practice, "doing", being primary. The theory should serve the practice: it enables us to consider what to do; it enables us to plan by predicting what reactions will follow our actions; and it enables us to reflect whether what we did was right or wrong, the best or merely an acceptable solution. ${ }^{16}$ We dislike being inconsistent in our beliefs, and we dislike our beliefs and action being inconsistent. ${ }^{17}$ Theory helps us identify apparent inconsistencies, and to address them. What it cannot do is teach us how to act effectively, because speculative knowledge, however valuable in itself, cannot substitute for the experiential knowledge that nous requires. ${ }^{18}$ Of course this reversal of our understanding of the relationship between base (necessary) and superstructure (optional) may threaten some academics as it undermines the kudos of the forms of knowledge and reasoning upon which their status depends.

The division made by Bentham between the expositor of the law and the censor of the law generates theory-induced blindness. Specifically, the product of the role of the expositor creates the feeling that the exposition of the law has a given quality. However, the exposition is a construct, and it has been produced for some purpose or other. In Bentham's classic account it was produced to allow an evaluation of the law; it was ancillary to Bentham's desire to censor the law from a utilitarian evaluative standpoint. Despite this well known incompleteness inherent in the exposition it still generates a sense of inevitability, a matter of fact quality. It is taken for granted that the freedom of professional lawyers' movement is defined by the exposition of the substantive law and procedure. However, this is patently not true. Legal professionals can, and do, influence

16 The inappropriateness of theoretical, or in legal education doctrinal, impulses for informing practice is brought out by the role of reflective criticism in ethical argument, Bernard Williams, Ethics and the Limits of Philosophy (2006) Routledge: Abingdon at 116-117: "The main consequence that this discussion has for ethical argument is that reflective criticism should basically go in a direction opposite to that encouraged by ethical theory. Theory looks characteristically for considerations that are very general and have as little distinctive content as possible, because it is trying to systematize and because it wants to represent as many reasons as possible as applications of other reasons. But critical reflection should seek for as much shared understanding as it can find on any issue, and use any ethical material that, in the context of reflective discussion, make some sense and commands some loyalty." Doctrine wants exclusive principles and rules with as few exceptions as possible. Practice wants to find common ground, avoid unnecessary conflict, and argue persuasively, which entails arguing in terms of values recognised by the other side. Broad and exclusive rules often give no useful guidance for specific situations (one always has to check the exceptions - which in practice are often more copious than the specific circumstances encompassed in the rule) that require inclusive thinking (demonstrating why the other side is applying the wrong exclusive rule risks hardening the interaction around principled differences - the most intractable of mind sets).

17 Cognitive dissonance is the term coined by Leon Festinger and his co-workers for this psychological discomfort, cognitive dissonance was explored in: Leon Festinger, Stanley Schachter, Henry W. Riecken, Elliot Aronson, When Prophecy Fails (2008)Pinter \& Martin Ltd: London.

18 Ultimately, it may be a question of temperament. Some of us seek the one right answer that will enable us to argue with and from certainty: these are the natural theorists, the hedgehogs as the term is used in Ronald Dworkin, Justice for Hedgehogs (2011) Belknap Press: Cambridge Mass. Some of us seek an answer adequate to the problems we face: these are the natural practitioners, who strive to cope, and who sometimes find the time for reflection and development of expertise. The problem is not one peculiar to legal education. In cognitive theoretic terms it is this issue that divides Kahneman and Gigerenzer: See Gerd Gigerenzer, Bounded and Rational in Rationality for Mortals: How people cope with uncertainty (2008) Oxford University Press: Oxford. In political theory it is the difference between the "monist" and the "pluralist" in the terms coined by Isaiah Berlin The Pursuit of the Ideal in The Proper Study of Mankind: An anthology of Essays (1998) ed. Henry Hardy and Roger Hausheer, Fwd. by Noel Annan, Pimlico: London. In jurisprudence it is the difference between "transcendent" and "comparative" theories of justice as these terms are used by Amartya Sen, The Idea of Justice (2009) Allen Lane: London. 
the substantive and procedural systems of law in which they practice on behalf of client, the public interest, and collective professional self-interest. An entire aspect of legal practice is obscured by theory -induced blindness.

This is not to claim the theory inducing the blindness is necessarily false or useless. The theory is true if law, in practice and theory, is concerned with that which is expounded, in other words if exposition can be supported as an independent activity. However, what if law is not like Euclid's geometry: the exploration of the relationship between axioms of universal validity. What if law is more like a game played by us all in the way Wittgenstein came to understand language: ${ }^{19}$ a shared activity that had a meaning derived from the activity? In the game approach to law the key question is not: "How would one describe this?" The key question is: "How does one win?" The subject matter is not exposition of doctrine and procedure but techniques for effective service to client and the public. Not: what is law? Rather: how can law be used?

This placing of law in its context as activity is not a novel insight. In the words of Stephen Sedley: ${ }^{20}$ "Their ${ }^{21}$ argument that law is 'a social process where information is constructed, passed on and mediated through a myriad of ways' is of more than sociological interest, because it starts to shed light on the myth that the business of law is the ascertainment of truth. It is no such thing: the business of law is winning cases." The difficulty is to avoid theoretical obfuscation, theory-induced blindness, of legal practice and the use of law in practice, as Wittgenstein remarked of language:22 "Here we are in enormous danger of wanting to make fine distinctions ... the everyday languagegame is to be accepted, and false accounts of it characterised as false..”, or in Sedley's words: ${ }^{23}$ “... the product of an academic industry ... which has built edifices of often baffling elaboration on the work of earlier practice-orientated theorists such as H.L.A. Hart." Meaning in law is a search for the "practical sense of words" 24 and the purposive nature of the search is a vital and common "tacit presupposition" underlying legal language games. ${ }^{25}$

However, it is not only the aim of legal activity and education that is altered by this perspective on law as a contextually situated language game. It introduces the possibility of a social cognitive space, neither the subjective (isolated individual of Descartes) nor objective (the common-sense

19 Ludwig Wittgenstein, Philosophical Investigations (2009) Wiley-Blackwell: Chichester at [7] p. 8: "I shall also call the whole, consisting of language and the activities into which it is woven, a 'language-game",; at [23] p 15: "The word 'language-game' is used here to emphasize the fact that the speaking of language is part of an activity, or of a form of life."

20 Stephen Sedley, Declining the brief, in Ashes and Sparks: Essays on Law and Justice (2011) Cambridge University Press: Cambridge at 156.

21 John Morison and Philip Leith, Barrister's World: And the Nature of Law (1991) Oxford University Press: Oxford.

22 Ludwig Wittgenstein, Philosophical Investigations, Part II [161] at 210.

23 Stephen Sedly, This beats me, in Ashes and Sparks: Essays on Law and Justice (2011) Cambridge University Press: Cambridge at 329

24 Ibid.

25 Wittgenstein, Philosophical Investigations, Part II [31] at 188: “'But then they make a tacit presupposition.' Then playing our language -game always rests on a tacit presupposition." 
possibility of non-evaluative exposition deployed by Bentham; the view from nowhere ${ }^{26}$ ) but "subjunctive". 27 The subjunctive point of view is that of the game players. Subjunctive worlds are typically built upon repetitive actions or "habits" or rituals, similar to Aristotle's conception of character built upon habits of virtuous (or vicious) action. ${ }^{28}$ These habits are informed by the belief that beliefs are shared, and they make sense only given assumptions about other people's understanding (tacit presuppositions). The subjunctive is ritualistic in nature, rather than based upon sincerity of feeling, and it is a shared practice as much as a shared belief.

Legal practice has qualities typical of the subjunctive. Consider the rules of communication in court, a ritualistic elaboration of discourse norms of turn taking, not talking at the same time as each other, and appearing to listen to the other side. Pleading and rules of evidence are legal devices to produce brief, orderly expression that avoids obscurity and ambiguity for the professional participants in the legal language game. Legal procedure attempts to limit the communicative actions to those seen as necessary, ruling irrelevant or immaterial much that is of great concern to litigants, and lawyers take part under a professional ethics that requires they do not say what they know to be false. ${ }^{29}$

The process is game like or ritualistic because it is not concerned with any subjective or inner beliefs of the participants. Consider the right of an accused to face his accuser and make his defence on the basis of the evidence produced by the prosecution. It is not necessary for the legal professionals to believe a defendant is innocent in order to give effect to the presumption of innocence. We engage in behaviour that is based upon a "what if" - "what if the defendant is innocent?" 30 Legal fictions are of course formal exercises in "what if", and Bentham notoriously failed to distinguish legal fiction from legal falsehood and deception. ${ }^{31}$ The objective exposition brooked no subjunctive reality to be understood from the perspective of the participants and their shared understanding of the process. Thus, our shared subjunctive worlds are shared ways of acting as much as shared ways of understanding.

26 A single "objective" viewpoint that is outside of social action is implicit in Ayer's bold assertion in reference to the problem of induction, A.J. Ayer, Language Truth and Logic (2001) Penguin Books: London at p. 35 that: "... it is a fictitious problem, since all genuine problems are at least theoretically capable of being solved." The possibility of such a viewpoint is of course the subject of the book by Thomas Nagel, The View From Nowhere (1989) Oxford University Press: Oxford. An excellent review of the problem of the possibility of an objective viewpoint is given by Simon Blackburn, Truth (2005) Penguin Books: London.

27 A.B. Seligman and R.P. Weller and M.J. Puett and B. Simon, Ritual and its Consequences: An essay on the limits of sincerity (2008) Oxford University Press: Oxford.

28 Aristotle, The Nicomachean Ethics (London: Penguin Books, 2004) tr. J.A.K. Thomson.

29 See Paul Grice, Logic and Conversation, in Studies in the Way of Words (1989) Harvard University Press: Cambridge, Mass at pp. 26-27 for discussion of "conversational implicatures" such as those noted in the text.

30 H. Vaihinger, The Philosophy of "As if" (2009) Martino Publishing: Mansfield Centre, CT, tr. C.K. Ogden.

31 Jeremy Bentham, A Fragment On Government (1998) Cambridge University Press: Cambridge. 


\section{The Argument: and a few terms defined}

We argue in this paper that traditional doctrinal legal studies are inextricably bound up with the theory of exposition as a necessary precursor to evaluation. The virtue or excellence they seek is elegance in statement and application of general propositions descriptive of the law. We will call this "facility in exposition". Sometimes legal education also seeks to develop a capacity to evaluate the law by some intelligible and appropriate standard of evaluation, and we will call this capability "theoretical awareness". However, such expository education involves a blindness to features of the law that are brought into focus by viewing legal process as a shared activity giving rise to a subjunctive understanding. Viewing the law as a game allows a powerful and necessary alternative approach to legal education.

Clinical legal education tends to pull towards an approach to legal education that treats law as a game because it has an experiential orientation. It is based on a belief that what we can learn from doing has a value. Legal education founded on a theory of law as a game - law as activity in a rule structured social environment - has less concern with exposition, which is ancillary to the educational task. Clear exposition will be required, in explaining to a client, or in advocacy. However, excellence in exposition is not the only purpose of the enterprise. Theoretical evaluation of the law in general terms, as opposed to evaluation in terms determined by the needs of the client or the public interest being served, is generally only of use for rhetorical purposes. The purpose aimed at by law as a game, is successful service of the client or public interest. We will call the capacity that produces this end "practical nous". Thus, the virtue or excellence that is sought in legal education on this model, the desired outcome in terms of the development of the student, is practical nous and not facility in exposition or theoretical awareness.

Obviously, the inculcation, development, and assessment of practical nous raise many difficult, and some possibly intractable, problems. However, one area of activity that can go some way towards the nurturing of nous is intervention in the field of rule change. We term "rule entrepreneurs" those legal professionals who engage in litigation, legislative or administrative process, formal consultations, or social activism with a view to bringing about rule changes. Rule entrepreneurs may be involved in advancing the same interests as rule acceptors, but they are open to another field of activity. Practical nous especially in rule entrepreneurship relies upon an awareness of what might be possible, together with intelligence about what the client or public interest requires, and an ingrained realisation that resources are always limited. Deciding where and how to expend resources is the test of practical nous. To do this well requires: sophisticated understanding of the possible outcomes that are desired (the imperatives of the client, or public interest - avoiding assumptions imposed by legal categories and processes); as fully informed as possible awareness of the field of action (the structures of power and influence that operate); and an understanding of what resources are available (financial, legal, political, ideological, moral, psychological, not limited by preconceptions of typically legal action).

The remainder of this article begins at the difficult challenge of delimiting or describing the nature of "demonstrable practical nous" by deploying an example of litigation and legislative action undertaken by a firm of lawyers in the United States of America. No attempt is made 
to advance a formal definition of practical nous. ${ }^{32}$ Second, we reflect upon the ordinariness of rule entrepreneurship in legal practice. Then we use examples from the practice of clinical legal education to illustrate how legal education can allow students to take part in rule entrepreneurship. Hopefully, at this stage we will have established the prima facie desirability and utility of thinking about the development of practical nous as the aim of legal education. In concluding we return to the importance of theory-induced blindness in this area, and consider why clinical legal education may be more naturally supportive of a shift towards making practical nous the aim of legal education, and what this would mean in terms of an integration of clinical and academic emphases within the legal academy.

\section{The Lawyer Successfully Using Practical Nous: Same Sex Marriage in Vermont}

The following account rests upon earlier publications by Beth Robinson, and Scott Barclay with Anna-Maria Marshall. ${ }^{33}$ The activity of Susan Murray and Beth Robinson, two partners in the Vermont law firm of Langrock, Sperry and Wool, will be our focus in this account. They were two of the three attorneys that filed the claim that was upheld in substance by the Vermont Supreme Court as State $v$ Baker. ${ }^{34}$ The decision of the court was followed by the passage of Vermont Civil Union Law, Act 91, ${ }^{35}$ that granted same sex couples the right to enter Civil Unions that created rights and obligations identical to those created by marriage. ${ }^{36}$ This law has since been superseded by an Act to Protect Religious Freedom and Recognise Equality in Civil Marriage passed in 2009.

32 It is a concept if not a word that is deeply familiar. It reflects the nature of "counsel". We are trying for a concept that has family resemblances rather than strict definitional boundaries. Thus, as noted below the concept is congruous with Eskridge's equality practice. Eskidge recognises the balancing act between liberal right and communitarian fear, and sees familiarity as the strongest weapon for enhanced tolerance, acceptance and eventually full legal and social recognition. William N. Eskridge Jr. Equality Practice: Civil Unions and the Future of Gay Rights (2002) Routledge: New York, NY at xiii: "This is what I call equality practice. Equality for lesbians, gay men, bisexuals, and their relationships is a liberal right for which there is no sufficient justification for state denial - but it is not a right that ought to be delivered immediately, if it would unsettle the community. So equality comes on little cat's feet." To ignore social norms, or to demand as of right everything that could be demanded as of right, is likely to set off a damaging reaction, so it is better not to do so. It also shares features with Kronman's "lawyer-statesmen" as can be seen in this descriptive account: "possessed of great practical wisdom, devoted to the public good but keenly aware of the limitations of human beings and their political arrangements"; Anthony Kronman, The Lost Lawyer: Failing Ideals of the Legal Profession (1993) Harvard University Press: Cambridge, Mass at 12. What we are trying to capture is not some novel aspect of legal practice, it is familiar but elusive, especially in a legal education context. It is also more general than public interest or cause lawyering. Commercial lawyers need, and the best have, practical nous. Indeed, there are many examples of rule entrepreneurship from commercial practice, a few aspects of which are noted below.

33 Beth Robinson, The Road to Inclusion for Same Sex Couples: The Lessons From Vermont (2001) 11 Seton Hall Const. L. J. 237; Scott Barclay and Anna-Maria Marshall, Supporting a Cause, Developing a Movement, and Consolidating a Practice: Cause Lawyers and Sexual Orientation Litigation in Vermont, in The Worlds Cause Lawyers Make: Structure and Agency in Legal Practice, ed. Austin Sarat and Stuart Scheingold, (2005) Stanford University Press: Stanford, CA. See also: William N. Eskridge Jnr, Equality Practice: Civil Unions and the Future of Gay Rights, (2002) Routledge: New York, NY at pp. 43-82.

3410 Vt. L. Wk. 363 (Vt. December 20, 1999). The third was Mary Bonauto of Gay \& Lesbian Advocates \& Defenders. The text of the brief is available in (1999) 5 Mich j Gender \& L 409.

35 Vt. Pub. Act 91, 2000 session.

36 "Partners to a civil union shall have all the same benefits, protections and responsibilities under law, whether they derive from statute, administrative or court rule, policy, common law, or any other source of civil law, as are granted to spouses in a marriage." 
The account below focuses upon the period between 1995 and 2000.

The involvement of Murray and Robinson in campaigning for same sex marriage developed from their client base and earlier public interest work involving gay and lesbian couples. In 1989 Murray had offered the firm's aid to a smaller firm acting in a case concerned with the guardianship of a child whose biological mother had been killed in an accident. Her partner, who had been co-parenting the child since his birth, was trying to establish her right to his guardianship. The case, In re Hamilton (1989), received a lot of press coverage and Langrock, Sperry and Wool became known as a firm supportive of gay couples. This led to significant private client work, concerned with powers of attorney, wills and trusts, and the guardianship and adoption of children, as well as problems arising from the breakdown of long-term same sex relationships: the structuring of private transactions and use of public law mechanisms to try and generate rights for same sex couples similar to the rights the law would normally grant to married couples. As well as this private client work the firm also intervened in Adoption of B.L.V.D. and E.L.V.B (1993) by filing an amicus curiae brief. This case held that adoptive same sex step-parents were to be treated in the same manner as other step-parents for the purposes of adoption law, the judicial decision was later given statutory force. ${ }^{37}$ Thus, Murray and Robinson were very familiar with the difficulties generated for same sex couples by the legal refusal to allow them to marry each other - indeed, cobbling together legal arrangements to assuage these problems was a significant source of work for their firm.

In the light of the needs of their clients and the injustice they felt was generated by denying marriage to same sex couples Murray and Robinson decided to try and amend the legal situation in Vermont. The groundwork began in 1995 when they became founder members of Vermont Freedom to Marry Task Force. In the words of Robinson: ${ }^{38}$ "All the great case citations in the world won't get you to your goal if the political and educational context is wrong." The first task was one of building an organisation of activists, establishing links with potential allies, and generating public awareness and acceptance. Public meetings were held, and it is from such gatherings of supporters that litigants came forward for the test case, three couples willing to sue for the right to marry each other. Speakers went to church groups and community groups to make people aware of the real problems caused to same sex couples by the discriminatory law. From these meetings support was obtained and new activists emerged. People were trained to speak to media representatives and the general public about same sex marriage and a general educative effort was made, in an attempt to reach those who would be willing to support the cause, but who may never have given the problem any real thought. The effort to garner support and educate people would not stop when suit was filed in 1997. However, the grass roots activity was a vital preparation for the inevitable resistance the campaign would face after filing.

The case of State $v$ Baker was commenced in 1997, and the arguments were directed to the Constitutional provisions of the State of Vermont. ${ }^{39}$ Vermont has a "common benefits clause" that provides: ${ }^{40}$

37 15A V.S.A.

38 (2001) 11 Seton Hall Const. L. J. 237 at 241.

39 The original brief filed by Bonauto, Murray, and Robinson is available at: (1999) 5 Mich J Gender \& L 409.

40 Ch. 1 Article 7. 
"That government is, or ought to be, instituted for the common benefit, protection, and security of the people, nation, or community, and not for the particular emolument or advantage of any single person, family, or set of persons, who are a part only of that community ...."

The argument was that this clause, and the jurisprudence upon its meaning, made marriage laws that prohibited same-sex marriage unconstitutional, as it favoured one part of the community and there was no valid State purpose served by the discrimination. Essentially, this argument was accepted by the Vermont Supreme Court. However, rather than ruling prohibition of same-sex marriages unconstitutional the majority deferred any remedy in order to allow the legislature to consider the matter.

Thus, the third phase of involvement by Murray and Robinson was around the legislative consideration of the issue. Murray gave evidence to the House Judiciary Committee, and they both took part in organising evidence and lobby activity as part of the newly formed Vermonters for Civil Union Defense Fund (essentially organising the same activists as the Vermont Freedom to Marry Task Force). Also, they personally lobbied members of the legislature, a form of representation Robinson found very distinct from advocacy in litigation: ${ }^{41}$

"It's certainly different from litigation. As a lawyer, I'm used to crossing the street to avoid the judge if I'm in the middle of a trial lest I inadvertently walk into an ex parte contact. In the legislative process, on the other hand, I found myself prowling around the coatroom just hoping to catch a legislator for a quick, private conversation. The rules of the game are quite different, and sometimes a little messy."

Having decided to support the Civil Union Bill, despite reservations of principle, Murray and Robinson played an important role in the Bill's success. They also campaigned in the hotly contested elections of 2000 in Vermont, in which the issue of same sex marriage loomed large.

In the light of this account it is hoped we can illustrate what is meant by practical nous.

It certainly includes knowledge and skills normally associated with the legal professional. The possibility of the argument (based on the relatively more obscure Article 7, and not the Federal law) and the supporting judicial history of dealing with the provision was founded in knowledge; and had the quality of expertise rather than competence. ${ }^{42}$ The arguments deployed played heavily with a powerful analogy (the striking down of laws that prevented miscegenation in marriage) and with ethical arguments founded upon empathy for the individuals affected by the discrimination as individuals (problems of responsibility for children after tragic death, the exclusion of people from medical decisions concerning their life partner, arbitrary unfairness and insult) combined with a strong appeal to the local legal tradition for tolerance, progressive thinking and justice. Rhetorically, the briefs combined technical plausibility with appealing ethical arguments - inviting the Supreme Court to do the right thing and in so doing to advance a proud tradition. Thus, there is no argument here that practical nous can be built upon professional inadequacies; on the contrary high levels of professional skill are called for.

What may be more unusual for an aim of legal education is the realisation that the legal struggle had to also be located in a cultural or political struggle. Legal expertise is effective, it has traction,

41 (2001) 11 Seton Hall Const. L. J. 237 at 253.

42 The distinction we are making is between competence that tries to avoid being wrong by covering the bases, and expertise that exploits a clean focus and greatly increases the chances of success. 
when it is understood that legal argumentation is founded in broader social dialogue. What seems reasonable, or possible, or absurd is determined by the lay discourse. Thus, in a slave owning democracy Dred Scott $v$ Sandford seemed a reasonable defence of private property. ${ }^{43}$ Thus, in the context of the struggle against racist political parties in World War II, the burgeoning sense of collective responsibility of the welfare state, and the increasing effectiveness of the civil rights movement, Brown v Board of Education of Topeka seemed a possible judicial response to a policy of segregation in an area that fatally undermined hopes for equality of opportunity. ${ }^{44}$ Thus, in the context of consensual sexual acts between people of the same sex being criminal in most States the arguments in Singer $v$ Hara were absurd. ${ }^{45}$ That what is possible in legal argument is dependent upon broader discourse is both obvious and problematic for any transcendent account of law. Practical nous is not a transcendent account of law; it is demonstrated by dealing with the contingent and dependent nature of the law in society.

Murray and Robinson did not simply understand that social context matters; they intervened to shift the discourse. The activity of the Vermont Freedom to Marry Taskforce had directly beneficial impacts upon the litigation strategy. Discussion in different settings honed the arguments eventually used in court; the plaintiffs in the litigation came forward, and were able to prepare for a novel public role imposed upon them by their role in the litigation; the Taskforce provided a supportive environment in which the litigation could be discussed. Furthermore, political support and the resources of allies were secured for the activities of the Taskforce. However, the rationale of the group was the preparation of public opinion for the litigation. It was a self-conscious effort to shift the discourse towards one that would view gay and lesbian marriage as a realistic possibility, as a desirable possibility, and as an issue about being fair and decent to fair and decent people. As described by Robinson: ${ }^{46}$

43 (1857) 60 U.S. 393. Dred Scott was infamous not for confirming the status of the Scott's as slaves, as determined by the law of Missouri, but for gratuitously declaring Congress' use of its power to prohibit slavery in the territories unconstitutional and providing an explicitly racist justification for the exclusion of African Americans from citizenship. See: Walter Ehrlich, They Have No Rights (2007) Applewood: Lea Vander Velde, Mrs. Dred Scott (2009) Oxford University Press: New York, NY; for insight into the lives behind the litigation. Dred and Harriet Scott were not deliberately involved in a test case; they sought freedom on well established grounds, probably for the sake of their two daughters, and were surprised by judicial activism that denied them well established rights. Sanford may well have fought the litigation as a rule entrepreneur, opposed to any legal recognition of rights that might weaken slavery. Sanford was certainly an active lobbyist in his business life.

44 (1954) 347 U.S. 483. Kluger's account of the discussions that preceded the arguments before the Supreme Court in Brown makes dramatically clear that counsel decided it was possible the Court would overturn educational segregation, there were strong arguments that it was also possible that it would not do so, and that a more cautious policy that gave the Court the option to enforce the "equality" requirement in Plessy v Ferguson (1896) 163 U.S. 537 might be more prudent: Richard Kluger, Simple Justice (2004) Vintage Books: New York, NY at pp. $510-542$.

45 (1974) 11 Wn. App. 247. Barclay and Fisher argue that the Singer case was not a failed attempt to obtain recognition of same sex marriage, but rather an attempt to: "effectively reclaim ownership and legitimacy over the idea of same sex marriage", Scott Barclay and Shauna Fisher, Cause Lawyers in the First Wave of Same Sex Marriage Litigation, in Cause Lawyers and Social Movements, eds. Austin Sarat and Stuart Scheingold (2006) Stanford University Press: Stanford, CA at p. 96. 
"We raised these policyish issues during our public education work but, frankly, they were not the most important messages we share. Far more important were our stories - real stories about real people and the reality of our lives.... Those stories, and our willingness to be honest and open about our lives and our families, cut through the myths that bind gay and lesbian progress far more than any policy paper or research project ever could."

The key rhetorical shift is away from defining people by their sexual conduct (gay and lesbian marriage) and towards defining people as individuals, couples, and families who happen to be gay or lesbian. If this frame is accepted then it is obvious that treating such people differently is discriminatory, and therefore the refusal to allow them to marry requires justification. If enough church groups, media reports, and public discourse adopt that viewpoint then public discourse has been changed. That change to public discourse was the aim of the stories, meetings, discussions, and media appearances. That changed discourse provided the context that would allow the Supreme Court to accept the arguments addressed to it. Murray and Robinson not merely saw the importance of the public discourse; they acted effectively to shift it towards a discourse that saw the question as one about discrimination.

The suggestion here is not that legal education should have compulsory modules on organisation and mobilisation. The practical skills Murray and Robinson deployed were linked to but went beyond those necessary for legal practice. The feature of importance to legal education in this aspect of our account is the practical nous to realise the necessity for addressing the public discourse. An understanding of the reliance of successful legal advocacy upon the structure of lay discourse is important for the provision of expert legal services. Helping students to see the commonalities across the discourses is something legal education should be concerned with. Awareness of the vital links between discourses, and indeed between various lay discourse inter se as well as between lay discourse and legal, is vital in commercial contexts as much as in political ones. Indeed in the light of the practice of Langrock, Sperry and Wool the commercial and the political were undifferentiated in important respects.

The final aspect of the account considered here is the lobby activity that followed the judgment in State $v$ Baker. The judgment raised three related problems for Murray and Robinson, and all those involved with the campaign.

First, the refusal of the Supreme Court to grant the remedy sought was game changing. The litigation had been argued on a simple win or lose basis: either civil marriage between gay and lesbian couples should be recognised by Vermont, or the law should remain that marriage had to be between a man and a woman. Legal principle and logical consistency made anything less than equality of treatment a violation of citizens' rights. The new phase made the issue political not legal. Once in the political arena the possibility of compromises, such as Civil Union, was present. If the campaign was about legal redress through the courts then taking part in the political process undermined credibility and weakened bargaining position. Again Robinson's account highlights the nature of the issue as seen from her vantage:

"The Court acknowledged that the Vermont Constitution was there to protect gay and lesbian Vermonters as much as any other Vermonters, but then turned us over to the political process as if our constitutional rights were subject to popular vote."

In the spirit of practical nous the campaigners continued the campaign into the political arena. The problem was to achieve what was needed; the litigation was a preferred road to legal change, but 
the purpose was legal change. Realistically refusal to make political representations would have been to reduce the chances for an acceptable outcome. Also, the arguments and the representative resources were already in place as a result of the pre-litigation activities of the Taskforce, and the lawyers who had argued before and persuaded the Supreme Court had a unique weight behind the evidence they gave to the committee that was considering the issue on behalf of the Vermont legislature. ${ }^{47}$

Second, was the problem of what was appropriate for legal professionals to do in terms of conduct in connection with the political process. Giving evidence before the committee had been not dissimilar from public education and advocacy in court. Robinson, as noted above, found the lobby process disconcerting, because it is not subject to procedural safeguards familiar from litigation. We argue below that some of this discomfort is self-deluding, because lawyers have been involved in the political influence business for a very long time and remain active in the field today.

Third, and finally, the campaigners had a difficult choice to make when the committee reported. The principle of equal rights was recognised, but the politically charged decision to allow civil marriage was shied away from. The recommendation was for legislation to create a novel status for gay and lesbian couples, Civil Union, all the consequences of marriage but not the name. Without the support of those involved in the Baker litigation the Civil Union Bill was doomed. To give the Bill support was to compromise on an important principle. The Taskforce was essentially renamed as the Vermonters for Civil Union Defense Fund and the campaign put its weight behind the Bill. This was congruent with the arguments developed in the campaign and is our final example of practical nous derived from this account.

The arguments, in court and out, had led with stories of real people who had been insulted, disempowered, and harmed by the discrimination inherent in Vermont's marriage law. Civil Union was still insulting, but it empowered and avoided harming gay and lesbian couples and their families. If law is about justice and fairness in social life then the Civil Union was a vital step forward, it provided for an equality of legal consequences with marriage. It also allowed people to live with the reality of social and legal recognition for gay and lesbian relationships, and as Robinson puts it:

47 Murray and Robinson seem to have seen the shift from court to legislature, and from principle to political arrangement in an overwhelmingly negative light, for them the Supreme Court's timidity in remedial terms was a disappointment. However, Eskridge saw this aspect of the Vermont experience as a positive, because it allowed "equality practice" - the community to practice a more equal legal and social life in a movement towards full equality (as one might practice fishing without catching any fish). The account of equality practice (and the discussion of how it sits within jurisprudential theory) has strong congruence with the idea of practical nous, although equality practice is held out as appropriate to a specific area of law and practical nous is held out as a general model of law and as an aspiration for legal education. "So equality comes on little cats feet ... Theoretically, equality practice seeks a law-based synthesis: liberalism instructs us as to rights, communitarianism as to remedies ... Equality practice has the vice of messiness and the virtue of workability ... The advantage of equality practice - or something like it - is that it recognises both the need to accommodate new ideas and the inability of human beings and their communities to do so without a long process of education and personal experience." Eskridge (2002) at pp. xii-xv. Practical nous is seeing what is possible by being guided by the end sought rather than any given process, as with equality practice understanding that norms and laws are dynamically interrelated and that education and discourse and lived experience are all part of the situation is called for by practical nous. That is why it is so difficult to be good at it, it is not a skill based in repetition, but the ability to navigate the currents of change, more like white water canoeing, to use a metaphor favoured by Jeff Giddings in Keynote Speech 4, Backwaters and Cascades - A Navigation Guide for Efforts to Mainstream Clinical Legal Education IJCLE Conference 2012. 
"The sky hasn't fallen. The institution of marriage hasn't dissolved. Some Vermont families are a little more secure, and nothing's been taken away from anybody else."

Her hope when she wrote in 2002 was that Civil Unions would be a precursor to the recognition of marriage for gay and lesbian couples, and as noted above that day did finally arrive in 2009. The discourse had been altered and never returned to its earlier form despite a punishing political process in the elections that followed the passage of the Civil Unions Bill.

When Murray and Robinson accepted the redefinition of the process as political, took part in the committee and lobby process, and supported the compromise of Civil Union, their actions were once again characterised by practical nous. The aims of the campaign had been consistent and the arguments deployed congruent across the three phases of the campaign. The problems faced by the clients of Murray and Robinson had led to their commitment to the campaign. Those problems were addressed by the establishment of Civil Unions. The legally unprincipled compromise was a life-line to families struggling to be recognised and respected in Vermont society. Understanding what is possible in the face of the structure of the situation and the resources available is the essence of practical nous. This is what Murray and Robinson did when they accepted the need to give full support to a less than ideal, but practically important reform..$^{48}$

Once again we are not suggesting legal education demand lengthy study of the nature of political compromise and process. However, the case of State $v$ Baker demonstrates once again that politics and law are not hermetically sealed universes of discourse. They are linked. An awareness of the links is vital to a realistic understanding of the role of the lawyer. Clients and the public interest do not demand punctilious regard to legal process and legalistic propriety. The lawyer is retained to find answers to problems, and if the best answer is to shift public opinion through a strategic engagement with public discourse and to help give birth to reforming legislation or a change in the interpretation of law then that is one avenue open to the practising lawyer; that possibility should therefore be part of legal education. Hopefully, the account of Murray and Robinson's efforts has left the reader with a high level of respect for their professional skills and for their ability to act effectively outside the stereotypical role of the trial lawyer, but to deploy both sets of desirable qualities towards an appropriate aim for a legal professional.

\section{Rule Entrepreneurship and Legal Professional Practice}

A common perception of the professional role of lawyers is bound up with litigation and representation. Indeed, if we broaden this idea to include dispute settlement more generally, recognising the importance of negotiation, then it probably accords with the assumptions of many legal professionals, both within and outside of academia. However, it neglects three important aspects of professional practice: the structuring of transactions, the role of lawyer as agent, and the modification of rules (what we have termed above "rule entrepreneurship"). It is this last, role that our argument is focussed upon here. Our argument is that rather than taking the law as the given structure of action within which our students are called to operate, whether on behalf of clients or the public good, lawyers do, and always have, acted as rule entrepreneurs.

48 Here is Robinson on the principle of Civil Union (2001) 11 Seton Hall Const. L. J. 237 at 249: “... the Vermont Supreme Court opened the door to consideration of a 'separate-but-equal' regime for gay and lesbian couples in marriage by suggesting that after all these years of walking we were entitled to ride on the bus - but it might be okay to require us to sit in the back." 
William Blackstone serves as an example of the historical depth of rule changing role for lawyers. The author of the Commentaries on the Laws of England was involved in the passing of private Acts of Parliament, and the management of a rotten borough on behalf of his clients when he worked as a barrister. ${ }^{49}$

A contemporary example of the importance ascribed to professional involvement in rule changing is provided by the web site of the City of London Law Society, which lists seventeen committees:

“... drawn from the Society's membership, who meet regularly to discuss pending legislation, law reform and practice issues in their fields. These specialist Committees provide unique City expertise and have regularly influenced the Government's law reform activities." 50

This aspect of main-stream practice was emphasised by Marc Galanter in his seminal article Why the Haves Come Out Ahead: Speculations on the Limits of Legal Change. ${ }^{51}$ He noted that it is the lawyers who work for the "haves" (large companies, insurers, Government agencies) who he termed "repeat players" who are most effective in the arena of rule changing. It is the repeat players who have the interest, and the resources, to engage in legal activity directed to changing the legal rules, or the application of the legal rules, he lamented that in terms of efficacy: ${ }^{.2}$

"Paradoxically, those legal professions most open to accentuating the advantages of the "haves" (by allowing themselves to be "captured" by recurrent clients) may be most able to become (or have room for, more likely) agents of change, precisely because they provide more license for identification with clients and their "causes" and have a less strict definition of what are properly professional activities."

Thus, we have long known that a concern for the substantive and procedural content of the legal rules is an important part of the business of law. Specifically, that lawyers have always and still do concern themselves with rule change, that the profession is interested not just in what the law is, but what it will become.

We would suggest for the purpose of analysis and exposition that the policy role of the lawyer be divided into two activities:

A. Strategic litigation and lawyering and;

B. Lobby activity.

Obviously, and as was illustrated by our account of the introduction of Civil Union in Vermont, the two activities are not exclusive, but dynamically linked.

49 Wilfred Prest, Blackstone as a barrister (2010) Seldon Society, London at pp. 28-29.

50 http://www.citysolicitors.org.uk/Default.aspx?sID=754\&/ID=0 last accessed 12/09/2012

51 Marc Galanter, Why the "Haves" Come Out Ahead: Speculations on the Limits of Legal Change (1974) 9 Law and Society Review 95

52 Ibid. at p. 151. 


\section{A. Strategic litigation}

Those who have ever worked for large clients will know the fear that an adverse decision in the courts can induce in clients or groups of clients. The use of "strategic litigation" to obtain (or not obtain) decisions which may adversely impact on aspects of a client's business is well-known (see: Swotbooks.Com Ltd $v$ Royal Bank of Scotland plc for an example of refusing to take a point in commercial litigation to avoid a potentially damaging judicial review of a standard contract term)..$^{53}$

Galanter classified those who use legal processes as either "one-shotters" or "repeat players" and he generated "ideal types" of his categories. ${ }^{54}$ Thus, he sought to describe the typical repeat player and one-shotter, in order to highlight the systematic differences each type experience in encounters with legal process. The hypothesis is that these systematic differences are the causes of the observed behavioural differences across the two groups of users of legal process. Specifically, that the situation of each group explains why one group, the repeat players, is far more engaged in rule entrepreneurship than the other group.

For repeat players legal process is a normal work-place activity, they are familiar with the process and anticipate its demands, structuring transactions in litigation helpful ways, and generating records that will be available if litigation becomes necessary. Familiarity generates reputation and relationships with officials, as well as knowledge of the market for specialist legal and other professional assistance. The size and resources of the typical repeat player (typical examples would be insurance companies or Government agencies), and the routine nature of its use of legal process, mean that it can afford to treat individual litigation outcomes as business risks. This is because any one decision is unlikely to threaten the vital interests of a repeat player. Therefore, it can bargain from strength and risk the occasional loss through overplaying its hand. ${ }^{55}$ In similar fashion, and for the same reasons, repeat players can "play for the rules" because the result of a single dispute is not vital, and the opportunity to influence future cases may be far more valuable: ${ }^{56}$

"For the R[epeat] P[layer], on the other hand, anything that will favourably influence the outcomes of future cases is a worthwhile result. The larger the stake for any player and the lower the probability of repeat play, the less likely that he will be concerned with the rules which govern future cases of the same kind."

The situation of the one-shotter differs in all relevant respects. The one-shotter is involved in what is likely to be a once in a lifetime experience; she is unlikely to have kept records and almost certainly accepted as given the structure of the transaction as designed by the repeat player; she has no knowledge about the market for specialised professional services; and she has no established relationships or reputation to use or protect. For the one-shotter the outcome is felt to be vital, and the financial and psychological costs of losing in the legal process are likely to be seen as prohibitively high. The one-shotter does not plan to return to the arena again. Therefore, the one-shotter has no personal incentive to seek rule change, and the perceived risk of pursuing rule

53 [2011] EWHC 2025 (QB)

54 Marc Galanter, Why the "Haves" Come Out Ahead: Speculations on the Limits of Legal Change (1974) 9 Law and Society Review 95 at 98.

55 Ibid. pp. 98-103.

56 Ibid, at 100. 
change is far higher than for the repeat player. ${ }^{57}$

Thus, systematic differences in aims and resources between the groups that use legal processes predispose one group, the repeat players, toward rule entrepreneurship and the other, the oneshotter group, toward a sole focus upon the dispute at hand. This explains the "paradoxical" (perhaps counter-intuitive would be more accurate) outcome Galanter described in the quotation above. "Paradoxical" because the powerful and regular users of legal process, whose interest are most likely to be reflected already in current law and practice, are also the most energetically engaged in rule entrepreneurship through litigation. This role of the lawyer is prominent in normal commercial practice.

To some degree some of these systematic differences between repeat player groups and oneshotter groups have been reduced by the growth of specialist groups of lawyers acting for many one-shotters. Members of such professional organisations may act as rule entrepreneurs through strategic litigation, in a similar fashion to the use of test cases by cause lawyers. ${ }^{58}$ In the UK examples of such organisations include: the Immigration Lawyers' Practitioners Association; ${ }^{59}$ the Housing Law Practitioners Association; ${ }^{60}$ and the Association of Personal Injury Lawyers. ${ }^{61}$ All these professional organisations expressly identify development of the law and legal process as an aspect of their work. Through their activities they also increase the collective benefits that can be derived from successful test cases by sharing information on cases going through the lower courts. Thus, the impact on future litigation and negotiation is increased through use of the network, and individual members of the network can gain professional reputational benefits by assuming a rule entrepreneurship role. However, professional loyalty to the client means the strategic aspect of litigation must be subservient to the interest of the individual client, unlike a repeat player who can sacrifice its own interests in a dispute for its own long term advantage. Individual firms select and promote test cases, usually cases that can be funded through legal aid, which may result in political change. A recent example of self-conscious use of litigation to pursue a social justice agenda was actions brought by Public Interest Lawyers for judicial review of the government's Community Action Programme and Work Academy Schemes. ${ }^{62}$

57 Ibid. pp. 98-103. Galanter makes the valid point that analytically repeat players and one-shotters are independent groups to the "haves" and implied "haves not" of his title; however, as he notes, there is obviously a strong overlap between the memberships of the repeat player and the haves groups, and the one-shotters and the havenots groups. Ibid. pp. 103-104.

58 It is moot whether such organisations and their members should be thought of as cause lawyers or not. The tension between altruism and the need to make a living is always present, and it is in part a question of whether good intentions or effectiveness should be given most importance: see Austin Sarat and Stuart Scheingold, Cause Lawyering and the Reproduction of Professional Authority: An Introduction in Cause Lawyering: Political Commitments and Professional Responsibilities (1998) Oxford University Press: Oxford. Obviously our case study of Langrock, Sperry and Wool is an example of a profitable but socially engaged firm. A concern with nous would tend to emphasis effectiveness over good intentions.

59 http://www.ilpa.org.uk/pages/ilpas-influencing-work.html last accessed 30/05/2013.

$60 \mathrm{http}: / /$ www.hlpa.org.uk/cms/about-hlpa/ last accessed 30/05/2013.

61 http://www.apil.org.uk/campaigning last accessed 30/05/2013.

62 http://www.publicinterestlawyers.co.uk/news_details.php?id=263 last accessed 28/05/2013. See also: http://www. guardian.co.uk/society/2013/may/23/benefits-cap-catastrophic-effect-families?INTCMP=SRCH last accessed 28/05/2013. 


\section{B. Lobby activity}

The rule entrepreneurship of repeat players is likely to extend to political action as well as strategic litigation: ${ }^{63}$

"First, it pays an $\mathrm{R}$ [epeat] $\mathrm{P}$ [ayer] to expend resources in influencing the making of the relevant rules by such methods as lobbying"

Of course an organisation may not involve its lawyers in lobbying, and in this important respect for our purposes lobby activity differs from litigation. Litigation is universally recognised as mainstream legal service. However, involvement by law firms in lobbying activity on behalf of clients seems to be relatively common.

A very useful study by Matthew Darke was published in 1997 reviewed the activity of Australian national law firms as lobbyists in Canberra, the Federal capital. ${ }^{64}$ All nine of the largest Australian law firms were active, and most of the activity was on behalf of business corporations or commercial associations. ${ }^{65}$ Interestingly, the service was one the lawyers providing it characterised as going beyond mere representation, rather being informed by what we have termed here practical nous as the lawyers are involved in evaluating what it is sensible to attempt: ${ }^{66}$

"The law firms interviewed for this thesis were of the view that their lobbyists act as mediators because they inform their clients if a particular goal is unachievable."

Indeed, the description by Darke of the services aspired to by law large law firms for their business clients approaches a description of nous informed support, proactive as much as reactive, and concerned with all practical factors that influence business success and failure: ${ }^{67}$

"a comprehensive and proactive style of lawyering in which lawyers try to shape their clients'

legal, economic and political environment".

Clearly, what is being described includes rule entrepreneurship as part of comprehensive legal service.

Rule entrepreneurship may not be in the service of individual clients, as seems to be the case with the work of the City of London Law Society. ${ }^{68}$ One might describe the representation of

63 Marc Galanter, Why the "Haves" Come Out Ahead: Speculations on the Limits of Legal Change (1974) 9 Law and Society Review 95 at 100.

64 Matthew Darke, Lobbying by Law Firms: a Study of Lobbying by National Law Firms (1997) 56(4) Australian Journal of Public Administration 32-46.

65 Ibid. at p. 34.

66 Ibid. at p. 38.

67 Ibid. at p. 42.

68 http://www.citysolicitors.org.uk/Default.aspx?sID=754\&lID=0 last accessed 02/07/2012 
collective interest as a form of elite cause lawyering. ${ }^{69}$ However, it is likely that the majority of rule entrepreneurship by commercial law firms is driven by client service. The House of Commons Political and Constitutional Reform Committee in March 2012 accepted an estimation that 20 law firms in the United Kingdom currently engage in direct legislative lobbying of Parliament on behalf of specific clients. ${ }^{70}$ If the Australian experience that most law firm lobbying was to administrative bodies is representative, then this activity in the legislative field is probably a small part of the total activity at Westminster. Direct "client-based" lobbying by UK based law firms appears to be more prominent in engagement with European Union institutions. One firm in Brussels states on its website that: ${ }^{71}$

"Our government affairs lawyers and advisers assist clients by monitoring, lobbying and intervening in EU legislative and policy developments, through contacts with EU decisionmakers in the Commission, the European Parliament and the Council."

Less overtly, another indicates that:

"Our multidisciplinary and multilingual lawyers enjoy strong professional and personal contacts with European regulatory and legislative bodies, offering clients up-to-the-minute knowledge of procedures and policy priorities at the European level."72

Rule entrepreneurship by UK law firms through lobbying is alive and well. It is not only on the commercial side that such activity is a part of legal services. An organisation that represents perhaps more one-shotter clients than any other is Citizens Advice whose mission includes: "improve the policies and practices that affect people's lives" together with the more familiar provision of: "the advice people need for the problems they face". ${ }^{73}$ The Parliamentary activity of Citizens Advice is well-documented and a transparent example of lobbying practice in the public interest.

Public interest legal practice, or cause lawyering, tends to attract accusations of being "political" as opposed to "legal", in a way that echoes the asserted independence of expository (legal) and censorious (political) jurisprudence. In the light of this it is worth noting how much of the practice described by academics or practitioners as "cause" law is familiar from the "ordinary" practice we have already noticed above. Indeed, this has been reflected in the provisions of Ethical Canon 8.4 of the American Bar Association's Model Code of Professional Responsibility (1994) as cited

69 See: Ann Southworth, Professional Identity and Political Commitment among Lawyers for Conservative Causes and Laura Hatcher, Economic Libertarians, Property, and Institutions: Linking Activism, Ideas, and Identities among Property Rights Advocates both in Austin Sarat \& Stuart A. Scheingold, The Worlds Cause Lawyers Make: Structure and Agency in Legal Practice (2005) Stanford University Press: Stanford, CA. See also: Keven R. den Dulk, In Legal Culture but Not of It: The Role of Cause Lawyers in Evangelical Legal Mobilisation in Austin Sarat \& Stuart A. Scheingold, Cause Lawyers and Social Movements (2006) Stanford University Press: Stanford, CA. See finally: Keven R. den Dulk, Purpose-Driven Lawyers: Evangelical Cause Lawyering and the Culture War and Laura J. Hatcher, Of Windmills and Wetlands: The Press and the Romance of Property Rights both in Austin Sarat \& Stuart Scheingold, The Cultural Lives of Cause Lawyers (2008) Cambridge University Press: Cambridge.

70 http://www.publications.parliament.uk/pa/cm201213/cmselect/cmpolcon/153/15306.htm\#a5 last accessed 28/05/2013. The table was derived from: HM Government, Introducing a statutory register of lobbyists, Impact Assessment, January 2012.

71 http://www.whitecase.com/brussels/ last accessed 02/07/2012.

72 http://www.hoganlovells.com/brussels-belgium/ last accessed 02/ 07/2012.

73 http://www.citizensadvice.org.uk/index/aboutus.htm last accessed 02 /07/ 2012. 
by Galowitz: ${ }^{74}$

"Whenever a lawyer seeks legislative or administrative changes, he should identify the capacity in which he appears, whether on behalf of himself, a client, or the public. A lawyer may advocate such changes on behalf of a client even though he does not agree with them. But when a lawyer purports to act on behalf of the public, he should espouse only those changes which he conscientiously believes to be in the public interest."

In similar vein it has been noted that sometimes the most effective and persistent "cause lawyers" turn out to be the jobbing professionals rather than the ideologically motivated practitioners. ${ }^{75}$

However, the context of cause lawyering for oppressed client groups or left wing or progressive causes has increased the attention given to the rule changing activities of lawyers. Indeed, the feeling that rule entrepreneurship is not part of lawyers' traditional role undoubtedly informed the express and severe restrictions imposed in the United States of America upon Federally funded lawyers' freedom to undertake such activities a process described by Galowitz. ${ }^{76}$ This is one area where developments in the US and the UK are divergent, as can be seen from a consideration of the approved role of the Citizens Advice Bureaux (CABx), an organisation that provides an example of rule changing activity based upon the "representation" not of individual clients but of a social interest group in the UK. It is not usual to regard the CABx as a transgressive or radical organisation, and as we notice below law student placements at CABx are not uncommon, and serve as a real world example of the importance of rule entrepreneurship in contemporary legal education.

\section{Clinical Legal Education and Practical Nous}

Hopefully we have demonstrated above that doctrinal legal education is based upon a limited understanding of the nature of law and legal practice, and that this limited understanding has given rise to a limited perception, a limitation that has prevented important aspects of legal practice being perceived. One aspect of practice that has been obscured by this theoretical blindness is the rule entrepreneurship of legal actors, especially legal professionals. We have shown that there is plenty of rule entrepreneurship going on in legal practice, in mainstream private practice and in cause lawyering, which is located both within and outside the mainstream business of law. We have suggested a shift in theory will allow the subjunctive aspect of law to become visible, and the game like properties of law to come into focus. Finally, when this shift in awareness takes place we can realign the aspirational purposes of legal education to what we have called practical nous and illustrated by an example of legal practice in Vermont. So far we have not explored the links between clinical legal education, our conception of a subjunctive model of law and legal practice, and our concept of practical nous.

74 Paula Galowitz, Restrictions on Lobbying by Legal Services Attorneys: Redefining Professional Norms and Obligations (1994) 4 B.U. Public Interest Law Journal 39 at n. 151.

75 Our account of the Murray and Robinson has this feature, see also: Rohen Shamir and Sara Chinski, Destruction of Houses and Construction of a Cause: Lawyers and Bedouins in the Israeli Courts, in Cause Lawyering: Political Commitments and Professional Responsibilities, ed. Austin Sarat and Stuart Scheingold (1998) Oxford University Press, Oxford at 227-257; some tort and employment law practices allow the service of both clients and the public interest.

76 Paula Galowitz, Restrictions on Lobbying by Legal Services Attorneys: Redefining Professional Norms and Obligations (1994) 4 B.U. Public Interest Law Journal 39. 


\section{Practices}

It would be possible to argue that client advice and the provision of legal services through negotiation or adversarial process is more naturally understood (and therefore should be taught) in terms of client aims, and wins or losses than doctrine, rights, remedies and process; in other words that clinical legal education naturally pulls legal education away from the inculcation of faculty in exposition and theoretical awareness as ends in themselves. However, it is in those areas where theory induced blindness is operative that the educational potential of clinical legal education is greatest, and where opportunities are perhaps not being taken because of the lack of an articulation of a vision of legal education informed by practical nous. Therefore we shall note examples of clinical legal education operating in the space between exposition and evaluation. Indeed, it was realisation that the student clinical experience was generating understanding that was not explicable or classifiable within a doctrinal legal frame that began the process that led to this article.

Our experience has been that student placements with the CABx regularly generate student awareness of problems with the existing substantive laws and procedural rules. Students realise that the role of the advisor can be reciprocal, the lawyer gives out advice but learns from the client what is happening in the world. The collection of information to inform the legal reform process is an explicit part of the advisor's role in CABx. As CABx advisors students are required to develop a sense of whether law is just in the sense of being fair and apt, and whether the law is administered justly or unjustly; this necessary sense of justice being additional to needing to know what the law is, and how to negotiate the legal or bureaucratic processes. This sensitivity to justice in practice is required to meet the objectives of the organisation that the students have volunteered to serve. Our third year undergraduate Clinical Legal Education module involves placement with organisations such as CABx. The engagement with the law reform aspect of the organisation's work often provides students with an excellent basis to satisfy learning outcomes which relate to critical evaluation of the fairness or otherwise of the law. We have captured this opportunity for developing theoretical awareness, but the challenge is to exploit it as a bridge to the development of nous. The practice presents the opportunity, but without an articulation of what we seek it is very difficult to generalise from the experience and take full educational advantage.

Another aspect of our practice that facilitates theoretical awareness, and could be used to foster nous, is participation by our students in work for the Innocence Project. ${ }^{77}$ Our Innocence Project is also available to third year undergraduates on the Clinical Legal Education module. Though expressly not a campaigning organisation, the aim of the Innocence Network to which our project subscribes involves:

“...improv[ing] the criminal justice system by overturning convictions... and effecting reforms of the criminal justice system to prevent such wrongful convictions from occurring in the future."

Inevitably, the work that students engage in often involves their realising systemic weaknesses exist within both the process of criminal investigation and trial process, weaknesses which can lead to miscarriages of justice. This in turn can lead to awareness of the need for reform of the relevant statute, or reform of the manner in which the Criminal Cases Review Commission in England

77 http://www.innocencenetwork.org.uk/about-us last accessed 30/05/2013. 
and Wales interprets its statutory role, and thus develop an understanding of the role of rule entrepreneurship within legal practice.

A final and somewhat more unusual example from our own experience has been with students who are seeking to use experience working with an NGO in the Indian state of Kerala as part of this same module. Students working in Kerala have worked on projects which involved scrutinising proposed environmental legislation for the State legislature. Clearly these students had direct engagement with a rule changing process and gained insight into the processes that lead to legislative change. Cast in the role of legislator the problem of trying to anticipating how various interests could be affected by legal change becomes unavoidable.

Thus, awareness of the plasticity of policy aspects of the legal environment, awareness of the possibilities and limits upon rule entrepreneurship, are naturally embedded in Clinical Legal Education programmes already. It is from awareness of such factors as elements or aspects of legal practice that the development of practical nous can begin. Fransiscus Haupt's account of the University of Pretoria law clinic's activity shows how, after many years of development, a University law clinic can engage in rule entrepreneurship through direct lobbying: ${ }^{78}$

"It [the clinic] is also increasingly involved in advocacy, lobbying, as well as engaged scholarship, and research that sometimes informs government policy:"

We are aware of other examples from the practice of colleagues and made public though Journal conferences. Richard Owen's paper at the IJCLE conference in 2010 outlined a module delivered at the University of Glamorgan which engaged students in lobbying the Welsh assembly to achieve policy and legislative change. ${ }^{79}$ While the focus of the module was specifically on developing student engagement with public policy and political processes, the development of political understanding which this entails can feed directly into what we have termed practical nous, and provide an opportunity for the development of an understanding of rule entrepreneurship.

Finally, the Bill of Rights project created at Northumbria University engaged students on an extra-curricular basis in responding to a government consultation on proposals to replace the Human Rights Act 1998 with a British Bill of Rights. ${ }^{80}$ The Bill of Rights project involved students participating in the processes associated with legal change, involving a potentially fundamental constitutional change. This particular project was not formally assessed. However, such activities could be incorporated into assessed modules. Whether assessed or not the project illustrates how, with a relatively small institutional investment of resources, students can be enabled to engage with the actual processes associated with legal change. Engagement with such political or quasi-political processes quickly bring awareness of limits to the possible, an awareness that can be used to assist in the development of nous. For UK clinicians the use of Law Commission consultations, as a basis for a clinical module or extra-curricular law school activity, represents a clear opportunity to engage students in the process of rule change, and possibly even rule entrepreneurship.

78 Franciscus Haupt, University of Pretoria, South Africa, Towards "Clinic For All": The evolution of a South African University Law Clinic: from volunteerism to institutionalized community engagement, IJCLE conference paper 2012.

79 Richard Owen, Making a Difference: Using Clinical Legal Education for Policy Change IJCLE conference paper 2010.

80 Richard Glancey, Ronagh Craddock, and Rachel Dunn Northumbria Law School Students' Bill of Rights Project IJCLE conference paper 2012. 


\section{Conclusion}

Thus, it seems that although the Legislative Advocacy Clinic run by Professor Pottenger at Yale is unusual in its clear identification of policy work as legal education it is not alone in engaging upon such activity. ${ }^{81}$ We hope that in this article we have managed to articulate some of the reasons why such policy orientated clinical legal education is in fact not merely appropriate but should be central to clinical legal education and legal education more generally.

Legal education is inescapably influenced by the theories that inform educators. Clinical legal education has tended to be viewed as a rather theoretically barren area of legal education: focused upon polishing skills such as English composition and the drafting of business documents, note taking and filing, communication skills involved in client interview and advice giving, and presentational skills such as posture, elocution and rhetorical structure of arguments. Clinicians have had to struggle for equality of respect and contractual conditions. Those involved in clinical legal education know how ill informed such views are, and that the educational benefits of clinical legal education transcend such trade school caricatures in many ways. However, in an academy dominated by the presupposition that legal education is about facility in exposition and theoretical awareness clinical legal education is under constant pressure to try and justify itself in such terms. We have argued that these aims are fundamentally inadequate as they distort the very nature of law as a discipline. Law is meaningful in a practical context and as part of a social process that is game like in nature.

It is clinical legal education that most naturally allows this aspect of law to become apparent, and the aims of legal education should not be limited to those associated with doctrinal law but should include the cultivation of practical nous. As we have noted, this does not mean that exposition, or theoretical awareness should be discarded, but that they should take their subordinated place, along with clinical programs, in the development of those skills (intellectual as well as practical), personality traits (such as ethical behavior), and knowledge and understanding (including thinking like a lawyer) that together can begin the process of developing practical nous. In this context we can perhaps realize the full import for legal education of the well known observation by Lewin that: 82 "There is nothing so practical as a good theory". As a good theory both arises from practice and has practical applicability, the theory we need is the theory that will enable us to fully articulate the nature of practical nous. The practical aspect of clinic should put it in the centre of good legal theory, and thus at the centre of academic legal thought. Difficulties in harvesting the full potential gains from clinical legal education are in part generated by a blindness generated by a partial theory of law and practice in the academy.

81 Professor Pottenger delivered Tales from a Policy Clinic: Triumph, Tragedy 8 Tribulation - but no 'Trials', the opening key note presentation at the IJCLE Conference2012.

82 Kurt Lewin, Problems of Research in Social Psychology, in Resolving Social Conflicts and Field Theory in Social Science (1997) American Psychological Association, Electronic Edition, loc. 6858. 